\title{
Application of phototherapy in the treatment of psoriasis vulgaris
}

\section{Zastosowanie fototerapii w leczeniu łuszczycy zwyczajnej}

\author{
Magdalena Sadowska', Aleksandra Lesiak², Joanna Narbutt ${ }^{2}$
}

'Students' Research Association at the Department of Dermatology, Paediatric and Oncologic Dermatology, Medical University of Lodz, Poland

Department of Dermatology, Paediatric and Oncologic Dermatology, Medical University of Lodz, Poland

IStudenckie Koło Naukowe przy Klinice Dermatologii, Dermatologii Dziecięcej i Onkologicznej Uniwersytetu Medycznego w Łodzi, Polska ${ }^{2}$ Klinika Dermatologii, Dermatologii Dziecięcej i Onkologicznej Uniwersytetu Medycznego w Łodzi, Polska

\section{CORRESPONDING AUTHOR/} ADRES DO KORESPONDENCJI: Magdalena Sadowska Studenckie Koło Naukowe przy Klinice Dermatologii, Dermatologii Dziecięcej

i Onkologicznej Uniwersytet Medyczny w Łodzi ul. Kniaziewicza 1/5 91-347 Łódź tel.: +48505959159 e-mail: magdalena.sadowska. umed@gmail.com

\begin{abstract}
Psoriasis is a chronic inflammatory skin disease with a complex aetiology. One of the methods of treating psoriasis is phototherapy, and the main phototherapeutic modalities include NB-UVB and PUVA. Phototherapy is considered the first treatment choice in moderate to severe forms of the disease. In mild psoriasis, an indication to start phototherapy is unsatisfactory outcome of topical treatment. NB-UVB is the first choice of therapy, and PUVA is considered in cases where NB-UVB fails to provide a sufficient therapeutic effect. The benefits of phototherapy include high efficacy and a good safety profile. However, phototherapy requires compliance with appropriate rules of photoprotection, careful patient monitoring and assessment of eligibility for treatment. The study below presents the most recent data on the application of phototherapy in patients with psoriasis, including the principles of irradiation treatment in children and pregnant, women, as well as adverse effects and methods to prevent them.
\end{abstract}

\section{STRESZCZENIE}

Łuszczyca zwyczajna to przewlekła choroba zapalna skóry o złożonej etiologii. Fototerapia jest jedną z metod jej leczenia, a najczęściej wykorzystywane są naświetlania NB-UVB oraz PUVA. W postaci umiarkowanej do ciężkiej jest to metoda pierwszego wyboru. W łuszczycy łagodnej wskazaniem do wdrożenia światłolecznictwa są niezadowalające efekty leczenia miejscowego. NB-UVB stosuje się w pierwszej kolejności, leczenie PUVA rozważa się przy niedostatecznym efekcie NB-UVB. Zaletami fototerapii są jej duża skuteczność i niewiele działań niepożądanych. Należy jednak stosować zasady odpowiedniej fotoprotekcji, monitorowania pacjenta oraz kwalifikacji do leczenia. W artykule przedstawiono aktualne dane dotyczące zastosowania fototerapii w leczeniu łuszczycy z uwzględnieniem zasad naświetlań dzieci i kobiet w ciąży oraz działań niepożądanych i sposobów zapobiegania ich wystąpieniu.

Key words: treatment, phototherapy, psoriasis vulgaris, UVB, PUVA.

Słowa kluczowe: leczenie, fototerapia, łuszczyca zwyczajna, UVB, PUVA. 
Psoriasis is a chronic inflammatory skin disease with several clinical types, of which the most common one is psoriasis vulgaris. In addition to plaque psoriasis, which accounts for $>80 \%$ of clinical cases, the disorder comprises, among others, guttate and inverse forms, and psoriasis capitis. Treatment options comprise topical and systemic medications such as methotrexate, cyclosporin, acitretin, biologic drugs as well as phototherapy. A number of therapeutic options are available, and the choice of treatment modality depends on the severity of the disease. The efficacy of treatment is evaluated with the clinical response index PASI 75 (Psoriasis Area and Severity Index), which represents the percentage of patients who have achieved a 75\% reduction in their PASI score from baseline [1].

\section{AIM}

The aim of the study is to discuss the application of phototherapy as a treatment modality for psoriasis vulgaris.

\section{WHAT IS PHOTOTHERAPY}

Ultraviolet radiation (UV) has therapeutic applications in a number of skin diseases. Widely used treatment options include UVB (280-315 nm) and UVA (315-400 nm), divided on the basis of biological activity into broadband UVB (280-315 nm) and narrowband UVB (311-313 nm), UVA-2 (315-340 nm) and UVA-1 (340-400 nm) [2]. UVB interacts with cells in the epidermal layers, while UVA penetrates deeper into the dermis. The most significant benefit of phototherapy is believed to be the immunomodulatory effect on the skin's immune system achieved through the influence of UV radiation on the production of mediators and expression of surface receptors, leading to antiinflammatory and immunosuppressive effects, and inducing the apoptosis of pathogenetically important cells [3]. In addition, UVB also directly affects nuclear DNA, causing the inhibition of cell proliferation $[2,4]$.

A method based on UVA is photochemotherapy, referred to as PUVA (psoralen ultraviolet $\mathrm{A}$ ), which involves the combination of radiation with chemical compounds called psoralens. They sensitize cells to UVA radiation, and by intercalating between DNA base pairs, they inhibit replication. Another mechanism of action of PUVA involves the degradation of cell membranes through the formation of reactive oxygen species [5].

In recent years, interest has been growing in the use of blue-light therapy, i.e. treatment with visible blue light emitted by LED devices (453 nm).

\section{WPROWADZENIE}

Łuszczyca to przewlekła choroba zapalna skóry, najczęstszym jej typem jest łuszczyca zwyczajna. Występuje między innymi jako łuszczyca plackowata, która stanowi powyżej $80 \%$ przypadków choroby, kropelkowata, odwrócona, ograniczona do skóry głowy. W leczeniu stosuje się leki miejscowe i ogólne, takie jak metotreksat, cyklosporyna, acytretyna, leki biologiczne oraz fototerapię. Istnieje wiele schematów terapeutycznych, a wybór formy leczenia zależy od stopnia nasilenia choroby. Do oceny skuteczności zastosowanej terapii stosuje się wskaźnik odpowiedzi klinicznej PASI 75 (Psoriasis Area and Severity Index) określający odsetek pacjentów, którzy osiągnęli redukcję początkowego PASI o 75\% [1].

\section{CEL PRACY}

Celem pracy jest przedstawienie fototerapii jako formy leczenia łuszczycy zwyczajnej.

\section{CZYM JEST FOTOTERAPIA}

Promieniowanie ultrafioletowe (ultraviolet radiation - UV) znajduje zastosowanie w leczeniu wielu chorób skóry. Szeroko wykorzystywane są promieniowanie UVB (280-315 nm) oraz UVA (315-400 nm), podzielone ze względu na działanie biologiczne na szerokopasmowe UVB (280-315 nm), wąskopasmowe UVB (311-313 nm) oraz UVA-2 (315-340 nm) i UVA-1 (340-400 nm) [2]. UVB oddziałuje na komórki warstw naskórka, podczas gdy UVA dociera głębiej do skóry właściwej. Uważa się, że najważniejszym efektem fototerapii jest immunomodulujący wpływ na układ immunologiczny skóry poprzez działanie promieniowania UV na produkcję mediatorów i ekspresję powierzchownych receptorów, co prowadzi do działania przeciwzapalnego i immunosupresyjnego oraz indukuje apoptozę ważnych patogenetycznie komórek [3]. Ponadto UVB wpływa bezpośrednio na DNA jądrowe, co powoduje zahamowanie proliferacji komórek $[2,4]$.

Metodą opierającą się na UVA jest fotochemioterapia, nazywana PUVA (psolaren ultraviolet $A$ ), która oprócz promieniowania dodatkowo wykorzystuje związki zwane psoralenami. Uwrażliwiają one komórki na promieniowanie UVA, a wbudowując się pomiędzy pary zasad DNA, hamują replikację. Inny mechanizm działania PUVA to degradacja błon komórkowych poprzez tworzenie reaktywnych form tlenu [5].

W ostatnim czasie dużym zainteresowaniem cieszy się zastosowanie światła niebieskiego, tzw. blue-light, emitowanego przez lampy LED (453 nm), które wchodzi w skład promieniowania widzialnego. 


\section{STATUS OF PHOTOTHERAPY}

\section{IN THE TREATMENT OF PSORIASIS}

Phototherapy is an effective and inexpensive therapeutic modality which has relatively few adverse effects. It is recognized that the psoriatic involvement of more than $10 \%$ of body surface area represents an indication to initiate phototherapy or systemic treatment. Some patients, however, experience marked deterioration in the quality of life despite the fact that a smaller percentage of body surface area is affected, which should be considered in the selection of therapy [6]. The severity of plaque psoriasis is assessed using the PASI score, BSA (body surface area) and DLQI (Dermatology Life Quality Index). PASI or BSA > 10 and DLQI > 10 define moderate to severe psoriasis, while PASI, BSA and DLQI $\leq 10$ describe mild psoriasis. Cases of mild severity are treated topically, and where topical therapy is insufficient, phototherapy may be added. Moderate and severe psoriasis is an indication to start phototherapy or systemic treatment, which may be used either in combination or in monotherapy $[1,7]$. Narrowband UVB is the first line of treatment, and where it fails to provide satisfactory results, PUVA may be considered as the next line of therapy $[1,8,9]$.

\section{UVB RADIATION}

The development of lamps emitting narrowband UV radiation ( $311 \mathrm{~nm}$ ) has rapidly led to the substitution of traditional broadband UVB (BB-UVB) radiation, which was used therapeutically for many years, by $311 \mathrm{~nm}$ radiation $[6,10]$.

In European guidelines, the PASI 75 score for BB-UVB has been set at 75\% (with improvement expected within 4-12 weeks) [1]. American guidelines provide that initial improvement occurs within approximately 4 weeks of therapy, and on average 20-25 treatments are needed to induce remission which is maintained in $5 \%$ of patients after a year [6]. An extensive review of the literature showed that the mean PASI 75 for BB-UVB monotherapy was 73\%, and the mean percentage of patients achieving remission (or an improvement of $\geq 90 \%$ ) was 59\% [11].

Narrowband UVB phototherapy, which is also referred to as TL-01 or NB-UVB, is currently one of the most widely used therapeutic modalities [4]. The European guidelines provide that a regimen of NB-UVB treatments administered twice a week results in remission in $63-75 \%$ of patients within 20 weeks. According to the AAD (American Academy of Dermatology) guidelines the initial improvement may occur within 2 weeks of therapy, and on average 15-20 treatments are needed to induce remission which is maintained in $38 \%$ of patients after a year [6]. A review of the literature demonstrated that PASI 75 for NB-UVB was

\section{MIEJSCE FOTOTERAPII W LECZENIU ŁUSZCZYCY}

Fototerapia to metoda skuteczna, tania, powodująca stosunkowo niewiele działań niepożądanych. Uważa się, że zajęcie powyżej 10\% powierzchni skóry przez zmiany łuszczycowe jest wskazaniem do rozpoczęcia fototerapii lub leczenia ogólnego. Niekiedy pacjenci mają istotnie obniżoną jakość życia pomimo zajęcia mniejszej powierzchni, co należy uwzględnić w doborze terapii [6]. Do oceny stopnia ciężkości łuszczycy plackowatej używa się wskaźników PASI, BSA (body surface area) i DLQI (dermatology life quality index). Wartości PASI lub BSA > 10 i DLQI > 10 określają łuszczycę umiarkowaną do ciężkiej. Wartości PASI, BSA i DLQI $\leq 10$ oznaczają łuszczycę łagodną. W łagodnej postaci choroby stosuje się leczenie miejscowe, a gdy jest ono niewystarczające, można dołączyć fototerapię. Łuszczyca umiarkowana lub ciężka jest wskazaniem do fototerapii lub leczenia ogólnoustrojowego, które mogą być stosowane jednocześnie albo w monoterapii $[1,7]$. Początkowo stosuje się wąskopasmowe UVB, a gdy jest ono nieskuteczne, w następnej kolejności można rozważyć metodę PUVA $[1,8,9]$.

\section{PROMIENIOWANIE UVB}

Wprowadzenie lamp wąskopasmowych UV (311 nm) szybko spowodowało, że tradycyjnie stosowane przez wiele lat promieniowanie UVB szerokopasmowe (broadband UVB - BB-UVB) zaczęto zastępować promieniowaniem $311 \mathrm{~nm}[6,10]$.

Wytyczne europejskie określiły PASI 75 dla BB-UVB na 75\% (poprawa w czasie 4-12 tygodni) [1]. Amerykańskie zalecenia podają, że początkowa poprawa następuje po ok. 4 tygodniach terapii, średnio 20-25 zabiegów indukuje remisję, a po roku utrzymuje się ona u 5\% pacjentów [6]. W dużym przeglądzie piśmiennictwa wykazano, że dla BB-UVB w monoterapii średnie PASI 75 wyniosło 73\%, a średni odsetek pacjentów osiągających remisję (lub poprawę o $\geq 90 \%$ ) 59\% [11].

Fototerapia UVB wąskopasmowa, nazywana także TL-01 lub NB-UVB, to obecnie jedna z najpowszechniejszych metod [4]. W wytycznych europejskich określono, że stosowanie naświetlań NB-UVB 2 razy $\mathrm{w}$ tygodniu powoduje wystąpienie remisji w ciągu 20 tygodni u 63-75\% pacjentów. Zalecenia American Academy of Dermatology (AAD) podają, że początkowa poprawa może nastąpić w ciągu 2 tygodni, średnio 15-20 zabiegów indukuje remisję, a po roku utrzymuje się ona u $38 \%$ pacjentów [6]. W przeglądzie piśmiennictwa określono PASI 75 dla NB-UVB na $62 \%$, a odsetek pacjentów osiągających remisję (lub poprawę o $\geq 90 \%$ ) na $68 \%$ [11]. Stwierdzono większą skuteczność schematu stosowania terapii 3 razy w tygodniu niż 2 razy w tygodniu $[8,10]$. 
$62 \%$, and the mean percentage of patients achieving remission (or an improvement of $\geq 90 \%$ ) was $68 \%$ [11]. A regimen based on NB-UVB treatments administered 3 times per week was found to be more therapeutically effective than a twice-weekly regimen $[8,10]$.

A number of studies have highlighted the superiority of NB-UVB over BB-UVB in terms of better treatment outcomes and faster resolution of skin lesions [6]. Before starting irradiation treatments the minimal erythema dose (MED) should be determined. MED - defined as the lowest dose of radiation needed to produce visible erythema within 24 hours following exposure is useful for prescribing an appropriate treatment regimen $[1,4,5,10]$. A fragment of non-sun-exposed skin, e.g. on the back, is subjected to increasing radiation doses, and evaluated the following day. The initial dose of UVB according to the American guidelines should be $50 \% \mathrm{MED}$, and according to European recommendations - 70\% MED, followed by dosage increases during subsequent irradiations $[1,6]$. Another method of determining the dose is evaluation of skin phototype, however it requires greater caution [10].

UVB phototherapy combined with oral retinoids is linked to better clinical response. In addition, it allows a decrease in the cumulative dose of UVB, and a reduction in acitretin dose [12]. Topical retinoids (tazarotene) in combination with UVB may also produce a better therapeutic effect than in monotherapy [13]. Topical vitamin D analogues added to NB-UVB allow a reduction in the cumulative dose of UVB [14]. Data on methotrexate are ambiguous, though there are reports indicating potential benefits of combining methotrexate with UVB. Cyclosporin is a drug to be avoided during the UVB treatment $[1,6]$.

\section{PUVA}

PUVA is the second-line treatment (after NB-UVB) of psoriasis, combining UVA irradiation with the administration of photosensitizing psoralens. The agents can be used topically in the form of creams, solutions or baths (bath-PUVA), or orally (oral-PUVA).

A study comparing PUVA with placebo showed the former to produce similar therapeutic effects to systemic drugs. Considering the fact that PUVA is associated with fewer adverse effects, it should be considered prior to the introduction of conventional systemic treatment [9].

A comparison of therapeutic benefits associated with bath-PUVA and oral-PUVA found the two modalities to be similarly beneficial [15].

Oral psoralens include 8-methoxypsoralen (8MOP) and 5-methoxypsoralen (5-MOP). 8-MOP has a proven superiority, but 5-MOP has the advantage of lower incidence of nausea in the course of treatment [16]. Thirty minutes after topical application,
W wielu badaniach potwierdzono wyższą skuteczność NB-UVB w stosunku do BB-UVB w postaci lepszych efektów leczenia i szybszego ustąpienia zmian [6]. Przed rozpoczęciem naświetlań należy określić minimalną dawkę rumieniową (minimal erythema dose - MED), czyli najmniejszą dawkę promieniowania, która powoduje wystąpienie zauważalnego rumienia po 24 godzinach. Pozwala to ustalić właściwy schemat leczenia $[1,4,5,10]$. Na fragment skóry nieeksponowanej na słońce, np. plecy, podaje się wzrastające dawki promieniowania i dokonuje odczytu następnego dnia. Dawka początkowa UVB wg zaleceń amerykańskich to 50\% MED, a wg rekomendacji europejskich 70\% MED. Następnie zwiększa się dawki podczas kolejnych naświetlań $[1,6]$. Inna metoda wyznaczenia dawki polega na określeniu fototypu skóry, jednak podczas jej stosowania należy zachować większą ostrożność [10].

Stosowanie fototerapii UVB jednocześnie z retinoidami doustnymi powoduje lepszą odpowiedź kliniczną, pozwala zmniejszyć kumulacyjną dawkę UVB oraz umożliwia stosowanie niższej dawki acytretyny [12]. Również retinoidy stosowane miejscowo (tazaroten) w połączeniu z UVB mogą przynieść lepszy efekt niż stosowane w monoterapii [13]. Wydaje się, że analogi witaminy D stosowane miejscowo dołączone do NB-UVB zmniejszają kumulacyjną dawkę UVB [14]. Dane dotyczące metotreksatu są niejednoznaczne, istnieją jednak doniesienia, że jego łączne stosowanie z UVB może być korzystne. Lekiem, którego należy unikać podczas terapii UVB, jest cyklosporyna $[1,6]$.

\section{METODA PUVA}

PUVA to metoda drugiego wyboru w terapii łuszczycy (po NB-UVB), która łączy naświetlania promieniowaniem UVA z podaniem fotouwrażliwiających psoralenów. Wyróżnia się aplikację miejscową tych substancji w postaci kremów, roztworów lub kąpieli (bath-PUVA) oraz doustną (oral-PUVA).

$\mathrm{W}$ badaniu porównującym PUVA z placebo oraz leków ogólnych i placebo wykazano podobne efekty terapeutyczne PUVA i leków stosowanych ogólnoustrojowo. Ze względu na mniejszą liczbę działań niepożądanych powinno się rozważyć PUVA przed wdrożeniem konwencjonalnej terapii ogólnoustrojowej [9].

Porównując efekty terapeutyczne po stosowaniu bath-PUVA i oral-PUVA, stwierdzono, że są one podobne [15].

Do doustnych psoralenów należy między innymi 8-metoksypsolaren (8-MOP) oraz 5-metoksypsolaren (5-MOP). Wykazano większą skuteczność 8-MOP, ale zaletą 5-MOP jest rzadsze występowanie nudności w przebiegu leczenia [16]. Po 30 minutach od apli- 
and about 1-2 hours after oral administration, the patient receives UVA irradiation treatment at a dose determined on the basis of the minimal phototoxic dose (MPD), i.e. the lowest dose of radiation that produces skin erythema within 48-96 hours. Since the use of psoralens in PUVA leads to delayed erythema (within approximately 48-96 hours), irradiation treatments are usually applied 2-3 times a week, with a minimum 48-hour interval between sessions [6, 9].

The initial dose of UVA is 75\% MPD for oral-PUVA, and $30 \%$ MPD for bath-PUVA [1]. The dose can also be determined on the basis of skin phototype $[1,6]$.

A meta-analysis comparing the efficacy of different phototherapeutic modalities comprising 41 randomized trials (with a total of 2,416 patients) found that the mean PASI 75 in monotherapy was $73 \%$ for PUVA, 62\% for NB-UVB, and 47\% for bath-PUVA. It follows that PUVA is a more potent monotherapeutic modality, but nevertheless NB-UVB is used as the first-line phototherapy in the treatment of psoriasis. This may be due to the fact that NB-UVB is associated with fewer adverse effects and, perhaps more importantly, there is no evidence suggesting its carcinogenic potential [11].

The application of PUVA in combination with other drugs may have potentially beneficial effects. The most advantageous option seems to be combining PUVA with oral retinoids. Their synergistic activity causes a decrease in the total number of irradiation treatments, reduces exposure to UVA radiation, and lowers the risk of skin cancer [17]. The combination of PUVA with topical vitamin D analogues reduces the duration of PUVA therapy and leads to a better clinical response [18]. However, vitamin D analogues must be applied after irradiation treatment, as UV radiation causes the drugs to become inactive [6].

Importantly, PUVA must not be used together with ciclosporin, as the combination contributes to a significant increase in the risk of squamous cell carcinoma (SCC) [19].

Data on the use of methotrexate are ambiguous. It has been reported that the combination of PUVA with methotrexate may be therapeutically beneficial, but there have also been studies with opposite findings, with methotrexate identified as an additional risk factor for skin cancer [20,21].

\section{BLUE-LIGHT THERAPY}

The blue light wavelength of $453 \mathrm{~nm}$ has been shown to have a favourable therapeutic effect on psoriatic lesions. The mechanism consists in reducing the proliferation of keratinocytes and increasing their differentiation, as well as inhibiting the production of cytokines by dendritic cells, and inducing the apoptosis of T lymphocytes [22, 23]. kacji miejscowej oraz ok. 1-2 godzinach od aplikacji doustnej pacjent zostaje poddany zabiegowi naświetlania promieniowaniem UVA, a dawkę określa się na podstawie minimalnej dawki fototoksycznej (minimal phototoxic dose - MPD). Jest to najmniejsza dawka, po której na skórze po 48-96 godzinach wystąpi rumień. Stosowanie psoralenów w metodzie PUVA opóźnia wystąpienie rumienia (po ok. 48-96 godzinach), dlatego naświetlania stosuje się zwykle 2-3 razy w tygodniu $\mathrm{z}$ minimalną 48-godzinną przerwą pomiędzy sesjami $[6,9]$.

Początkowa dawka UVA wynosi 75\% MPD dla oral-PUVA oraz 30\% MPD dla bath-PUVA [1]. Można ją również określić na podstawie fototypu skóry $[1,6]$.

W metaanalizie obejmującej 41 badań, porównującej skuteczność metod fototerapii z randomizacją (w sumie 2416 pacjentów) wykazano, że w monoterapii PASI 75 podczas naświetlań PUVA wynosiło średnio 73\%, dla NB-UVB 62\%, a dla bath-PUVA $47 \%$. Metodą skuteczniejszą w monoterapii jest więc PUVA, jednak NB-UVB stanowi pierwszy wybór fototerapii w leczeniu łuszczycy. Może to być spowodowane mniejszą liczbą działań niepożądanych NB-UVB, zwłaszcza brak dowodów na potencjał kancerogenny [11].

Zastosowanie PUVA w połączeniu z innymi lekami może przynieść korzystne efekty. Najbardziej zasadne wydaje się dołączenie do PUVA-terapii retinoidów doustnych. Ich synergistyczne działanie pozwala na zmniejszenie całkowitej liczby naświetlań i ekspozycji na promieniowanie UVA oraz ogranicza ryzyko wystąpienia nowotworów skóry [17]. Połączenie PUVA z miejscowymi analogami witaminy D skraca czas trwania PUVA-terapii i skutkuje lepszą odpowiedzią kliniczną [18]. Należy jednak pamiętać, by stosować je po zabiegu naświetlania, ponieważ promieniowanie UV powoduje unieczynnienie analogów witaminy D [6].

Metody PUVA nie można łączyć z cyklosporyną, ponieważ połączenie to znacząco zwiększa ryzyko wystąpienia raka kolczystokomórkowego (squamous cell carcinoma - SCC) [19].

Dane dotyczące stosowania metotreksatu są niejednoznaczne. Istnieją doniesienia, że połączenie PUVA-terapii z metotreksatem może być korzystne, jednak są też prace, które temu zaprzeczają, określając metotreksat jako dodatkowy czynnik ryzyka rozwoju nowotworu skóry [20, 21].

\section{ŚWIATŁO NIEBIESKIE}

Wykazano, że długość fali promieniowania niebieskiego wynosząca 453 nm korzystnie wpływa na zmiany łuszczycowe. Mechanizm jego działania polega na zmniejszeniu proliferacji keratynocytów i nasileniu ich różnicowania, a także na hamowaniu 
In one of the studies, a significant improvement was achieved after 4 weeks in 40 patients with mild to moderate psoriasis, but complete resolution of skin lesions was not achieved [22]. A 12-week follow-up of 47 patients with mild psoriasis confirmed previous findings. No serious adverse effects were noted. More studies are needed, but the results so far show that it represents a promising method in the treatment of psoriasis [23].

\section{PHOTOTHERAPY IN CHILDREN}

Phototherapy is an effective treatment for psoriasis in children $[6,24]$. NB-UVB is the most preferred option in the paediatric population out of all available therapeutic modalities [24, 25]. In one of the studies, conducted in a group of 113 children $(53.5 \%$ suffering from psoriasis), the response to NB-UVB, PUVA, and UVB treatment among the patients with psoriasis was $92.9 \%, 83.3 \%$, and $93.3 \%$, respectively. PUVA was applied exclusively in children over the age of 12 [26]. PUVA irradiation is very rarely used in children because of evidence for a link between PUVA and an elevated risk of carcinogenesis. Age below 18 years is not an absolute contraindication to PUVA, and in specific cases it is an acceptable therapeutic option, though psoralens should preferably be applied topically on account of a shorter photosensitization period and fewer gastrointestinal adverse effects [6, 24].

In Poland, oral psoralens are approved for therapy from the age of 12 , so this is the age limit below which PUVA is not applied. UVB radiation is used in the paediatric population at a markedly higher frequency. The risk of skin cancer in patients treated with UVB phototherapy has not been clearly established, which is why close monitoring and assessment of patient eligibility for treatment are extremely important $[24,25,27]$. Since paediatric patients have a longer life expectancy than adults, the likelihood of late adverse effects can be higher, given that the children may require multiple irradiation treatments in the future [27]. The age limit for UVB is often adjusted on a case-by-case basis, taking into account, among other aspects, the assessment of whether the child is able to remain motionless during irradiation treatment [24].

Indications to starting phototherapy include extensive skin involvement, marked severity of skin lesions [24, 25], unsuccessful topical treatment [6, 25, $27,28]$, as well as contraindications to systemic therapy $[24,25]$.

\section{PHOTOTHERAPY IN PREGNANCY}

Pregnancy is not a contraindication to UVB irradiation $[1,6]$. This therapeutic modality is considered produkcji cytokin przez komórki dendrytyczne oraz indukcji apoptozy limfocytów T $[22,23]$.

Po 4 tygodniach u 40 pacjentów z łuszczycą łagodną do umiarkowanej osiągnięto istotną poprawę, nie doszło jednak do całkowitego ustąpienia zmian [22]. Obserwacja 12-tygodniowa 47 pacjentów z łuszczycą łagodną potwierdziła poprzednie wyniki. Nie wystąpiły żadne poważne działania niepożądane. Należy przeprowadzić większą liczbę badań, jednak dotychczasowe wyniki wskazują, że jest to obiecująca metoda terapii w łuszczycy [23].

\section{FOTOTERAPIA U DZIECI}

Fototerapia to skuteczna forma leczenia łuszczycy $\mathrm{u}$ dzieci $[6,24]$. Z dostępnych metod w populacji pediatrycznej najbardziej preferowana jest NB-UVB [24, 25]. W jednej z analiz wśród 113 dzieci (53,5\% chorowało na łuszczycę) odpowiedź na leczenie metodą NB-UVB, PUVA, UVB uzyskało odpowiednio 92,9\%, 83,3\%, 93,3\% pacjentów z łuszczycą. Metodę PUVA zastosowano tylko u dzieci powyżej 12. roku życia [26]. Naświetlania PUVA są bardzo rzadko stosowane $\mathrm{u}$ dzieci ze względu na udowodnione zwiększone ryzyko nowotworzenia. Wiek poniżej 18 lat nie jest bezwzględnym przeciwwskazaniem do PUVA-terapii i w szczególnych przypadkach dopuszczalne jest jej wykorzystanie, jednak należy preferować miejscową aplikację psoralenów ze względu na krótszy efekt fotouwrażliwiający i mniej działań niepożądanych ze strony układu pokarmowego [6, 24].

W Polsce preparaty doustnych psoralenów są zarejestrowane od 12. roku życia, więc poniżej tego wieku nie stosuje się PUVA-terapii. Promieniowanie UVB jest zdecydowanie częściej wykorzystywane w populacji pediatrycznej. Ryzyko wystąpienia nowotworów skóry u pacjentów poddawanych fototerapii UVB nie jest jednoznacznie określone, dlatego niezwykle ważna jest ich baczna obserwacja i odpowiednia kwalifikacja [24, 25 , 27]. Dłuższa niż u dorosłych przewidywana długość życia może zwiększać prawdopodobieństwo wystąpienia odległych skutków niepożądanych ze względu na to, że dzieci te mogą wymagać wielokrotnych naświetlań w przyszłości [27]. Granicę wieku dla UVB często określa się indywidualnie, uwzględniając m.in. to, czy dziecko jest w stanie pozostać bez ruchu podczas naświetlań [24].

Za wskazania do wdrożenia fototerapii uznaje się rozległe zajęcie skóry, znaczne nasilenie zmian [24, 25], brak efektów leczenia miejscowego [6, 25, 27, 28], jak również przeciwwskazania do leczenia ogólnego [24, 25].

\section{CIAZŻA A FOTOTERAPIA}

Ciąża nie stanowi przeciwwskazania do stosowania naświetlań UVB [1, 6]. Są one uważane za sku- 
to be both effective and safe, and in pregnant women with mild psoriasis it is used as second-line treatment after failure of topical therapy (BB-UVB when NB-UVB is unavailable) [29-31].

NB-UVB should be considered as first-line treatment in cases requiring a systemic approach, i.e. in severe forms of the disease [6, 29].

There have been isolated reports showing that UVB phototherapy can lead to a decrease in folic acid concentration, so folic acid supplementation is recommended during UVB irradiation treatment. Also, caution should be taken in pregnant women to avoid excessive body heating during treatment [29-31].

Since PUVA is classified as pregnancy category C, it should not be used in pregnant women because of potential mutagenic and teratogenic effects of psoralens, and in breastfeeding women in view of the fact that psoralens are excreted into human milk [1, 29-31].

\section{ADVERSE EFFECTS}

The adverse effects of phototherapy can be divided into early (occurring during or within a relatively short time after irradiation treatment) and late, including the distant effects of multiple UV exposures of the skin. A metaanalysis evaluating the incidence of adverse effects associated with various forms of phototherapy, conducted in a large group of 2,416 patients, has shown that phototherapeutic modalities very rarely cause serious adverse effects, especially those that would require discontinuation of irradiation treatment. Only in $2 \%$ of NB-UVB treated patients adverse effects led to the discontinuation of irradiation treatment. For other phototherapeutic methods, the values were not high either $(4.6 \%$ for BB-UVB, 5\% for PUVA and 0.7\% for bath-PUVA), thus proving a high safety profile of phototherapy [11].

The most common early adverse effect of UVB radiation is erythema, mostly of mild severity. Other possible adverse effects include a burning sensation on the skin and pruritus which, if not accompanied by erythema, only requires regular use of emollients. There have also been cases involving reactivation of skin infections, e.g. with HSV, or induction of photodermatoses $[1,4,6,32]$.

The most prevalent early adverse effects of PUVA include delayed erythema, pruritus and nausea, occasionally accompanied by vomiting. Nausea associated with oral administration of psoralens does not occur during bath-PUVA. In order to lessen the effect, psoralens can be taken with a small meal. There have also been reports of headaches occurring during oralPUVA treatment, as well as activation of skin infections (HSV) and induction of photodermatoses such as polymorphic light eruption $[1,6,9,32]$. teczne i bezpieczne, a u kobiet w ciąży z łuszczycą łagodną są metodą drugiego wyboru w przypadku nieskuteczności leczenia miejscowego (BB-UVB, gdy NB-UVB jest niedostępne) [29-31].

Terapię NB-UVB powinno się rozważyć początkowo, gdy wymagane jest podejście systemowe, czyli w ciężkiej postaci łuszczycy [6, 29].

Istnieją pojedyncze doniesienia, że fototerapia UVB może zmniejszać stężenie kwasu foliowego, dlatego podczas jej stosowania zaleca się jego suplementację. Należy też uważać, by nie dochodziło do przegrzania organizmu kobiety ciężarnej [29-31].

Terapia PUVA ma kategorię C dla kobiet w ciąży. Nie należy jej stosować zarówno u ciężarnych ze względu na potencjalne działanie mutagenne i teratogenne psoralenów, jak i u kobiet karmiących piersią ze względu na fakt, że psoraleny są wydzielane do mleka [1, 29-31].

\section{DZIAŁANIA NIEPOŻĄDANE}

Działania niepożądane fototerapii można podzielić na wczesne, występujące w trakcie leczenia lub w stosunkowo krótkim czasie po naświetlaniach oraz na późne, obejmujące odległe skutki wielokrotnego oddziaływania promieniowania UV na skórę. W metaanalizie określającej częstość występowania działań niepożądanych podczas stosowania różnych form fototerapii u dużej grupy 2416 pacjentów stwierdzono, że metody te bardzo rzadko powodują poważne działania niepożądane, zwłaszcza takie, które prowadzą do konieczności przerwania naświetlań. Tylko u $2 \%$ pacjentów stosujących NB-UVB działania niepożądane były powodem odstąpienia od naświetlań. Dla innych metod fototerapii wartości te również nie były wysokie $(4,6 \%$ dla BB-UVB, $5 \%$ dla PUVA oraz 0,7\% dla bath-PUVA), co potwierdza duży profil bezpieczeństwa fototerapii [11].

Najczęstszym wczesnym działaniem niepożądanym promieniowania UVB jest rumień, głównie o łagodnym nasileniu. Może też wystąpić uczucie pieczenia i świąd, które bez współistniejącego rumienia wymagają jedynie regularnego stosowania emolientów. Zdarza się również, że w przebiegu naświetlań dochodzi do reaktywacji infekcji skórnych, np. zakażania wirusem HSV lub indukcji fotodermatoz $[1,4,6,32]$.

W przypadku PUVA-terapii najczęstsze wczesne działania niepożądane obejmują wystąpienie rumienia, który pojawia się z opóźnieniem, świądu oraz nudności, niekiedy z towarzyszącymi wymiotami. Nudności wiążą się z przyjmowaniem doustnych psoralenów, nie występują podczas bath-PUVA. Można próbować je złagodzić poprzez jednoczesne spożycie niewielkiego posiłku. Opisywane są także bóle głowy występujące w trakcie stosowania oral-PUVA, aktywacja infekcji skórnych (HSV) i indukcja fotodermatoz, takich jak polimorficzna osutka świetlna $[1,6,9,32]$. 
The use of phototoxic or photoallergic drugs during irradiation treatment may occasionally lead to adverse effects. Most of them are caused by radiation within the UVA spectrum, and the drugs have practically no effect on UVB MED. Consequently, the assessment of MPD for the purpose of establishing the starting dose of PUVA should be performed while the patient uses all prescribed drugs $[1,9,32]$. Phototoxic reactions, predominantly in the form of acute burn injuries, are more common than photoallergic reactions. The main drugs that should be avoided during PUVA treatment include topical and oral nonsteroidal anti-inflammatory drugs, oral antibiotics chiefly tetracyclines and fluoroquinolones, diuretics, and a large group of antipsychotic agents - mainly phenothiazine derivatives [33].

Late adverse effects associated with UVB radiation include photoaging which involves the formation of teleangiectasias and wrinkles $[6,10]$. The ability of UV radiation to cause damage to the DNA structure, and the impact on the immune system, lead to a proven increase in the risk of skin cancer following excessive exposure to natural UV radiation. There are concerns that artificial UV radiation in the form of phototherapy may also play a part in carcinogenesis [34].

As yet, UVB phototherapy has not been shown as a contributing factor to the formation of skin cancers, including SCC, BCC and malignant melanoma [35, 36].

In addition to accelerated skin photoaging, late adverse effects of PUVA include the so-called PUVA lentigines (PUVA-associated lentigo spots), and PUVA-keratoses, i.e. PUVA-induced keratotic skin lesions $[9,37]$.

Despite previous concerns, it has been demonstrated that with proper eye protection PUVA exposure does not lead to an increased risk of cataract [38].

In contrast to UVB, PUVA has a proven link to an elevated risk of developing non-melanoma skin cancers (NMSC), i.e. SCC and BCC. The correlation is particularly strong between SCC and long-term PUVA, and the risk rises with increasing cumulative doses $[39,40]$. An especially notable increase in the risk of NMSC is seen in patients after $>200$ PUVA irradiation sessions $[6,9]$. The risk of SCC persists for up to 15 years after the discontinuation of PUVA treatments, while the risk of developing BCC rises with time after the completion of PUVA therapy [41].

The correlation between PUVA and malignant melanoma has not as yet been entirely elucidated. The first report suggesting an increased risk of cutaneous melanoma refers to the American population. An observational study performed on a group of 1,380 patients demonstrated an elevated risk 15 years after the onset of the first PUVA treatment, especially among patients receiving a large number of PUVA treatments $(\geq 250)$ [42]. However, European studies
Stosowanie leków fototoksycznych lub fotoalergicznych $\mathrm{w}$ trakcie naświetlań prowadzi niekiedy do wystąpienia działań niepożądanych. Większość $z$ nich spowodowana jest przez promieniowanie UVA. Leki te właściwie nie wpływają na MED UVB. Dlatego ocenę MPD do ustalenia dawki początkowej PUVA należy przeprowadzać podczas stosowania wszystkich leków, jakie przyjmuje pacjent $[1,9,32]$. Częściej niż reakcje fotoalergiczne występują reakcje fototoksyczne, głównie w postaci ostrych odczynów oparzeniowych. Do najważniejszych leków, których należy unikać w czasie naświetlań PUVA, należą stosowane miejscowo oraz doustnie niesteroidowe leki przeciwzapalne, doustne antybiotyki - najczęściej tetracykliny, fluorochinolony, diuretyki oraz duża grupa leków przeciwpsychotycznych - głównie pochodne fenotiazyny [33].

Do późnych działań niepożądanych promieniowania UVB należy fotostarzenie, obejmujące między innymi powstawanie teleangiektazji i zmarszczek $[6,10]$. Promieniowanie UV ma zdolność uszkadzania struktury DNA oraz wpływ na układ immunologiczny, co jest przyczyną udowodnionego wzrostu ryzyka wystąpienia nowotworów skóry po nadmiernej ekspozycji na naturalne promieniowanie UV. Istnieje obawa, że stosowanie sztucznego promieniowania UV w formie fototerapii również może prowadzić do kancerogenezy [34].

Do tej pory nie udowodniono, aby fototerapia UVB wpływała na powstawanie nowotworów skóry, zarówno SCC, raka podstawnokomórkowego (basal cell carcinoma - BCC), jak i czerniaka $[35,36]$.

Do późnych działań niepożądanych PUVA-terapii, oprócz przyspieszonego fotostarzenia skóry, należą również tzw. PUVA lentigines (plamy soczewicowate związane z PUVA) oraz PUVA-keratoses, czyli rogowacenie indukowane przez PUVA $[9,37]$.

Mimo wcześniejszych obaw wykazano, że jeśli prawidłowo chroni się oczy, naświetlania PUVA nie powodują zwiększonego ryzyka wystąpienia zaćmy [38].

W przeciwieństwie do UVB, w przypadku PUVA istnieje udowodniony wzrost ryzyka zachorowania na nieczerniakowe nowotwory skóry (non-melanoma skin cancer - NMSC), czyli SCC i BCC. Dotyczy to zwłaszcza SCC, gdy terapia PUVA stosowana jest długotrwale. Ryzyko to zwiększa się wraz ze wzrostem dawki kumulacyjnej [39, 40]. Szczególny wzrost ryzyka rozwoju NMSC obserwuje się u pacjentów, którzy przeszli > 200 sesji naświetlań PUVA [6, 9]. Ryzyko wystąpienia SCC utrzymuje się nawet przez 15 lat od zaprzestania naświetlań PUVA, a dla BCC wzrasta wraz z czasem od zakończenia PUVA-terapii [41].

Związek PUVA z wystąpieniem czerniaka nie jest do końca poznany. Pierwsze doniesienie wskazujące na wzrost ryzyka wystąpienia czerniaka skóry dotyczy populacji amerykańskiej. Obserwacja grupy 1380 
to date have not confirmed this correlation. A Swedish study conducted in a cohort of 4,799 patients followed up for an average of 15.9 years found no increase in the incidence of malignant melanoma. The findings may be due to a difference in the therapeutic regimens prescribed in the USA and in Europe, and varying criteria applied for the selection of patients for the study [39].

Contraindications to phototherapy are listed in the table 1.

In order to prevent adverse effects of phototherapy, protective goggles should be used during treatments, and areas with increased sun exposure (face, neck, shoulders, hands) should be covered, provided that they are not affected by skin lesions. It is crucial to to cover the genital area during irradiation treatments, as failure to use genital protection has been found to be associated with an increased risk of genital cancer [43]. Patients should be educated so that they avoid excessive exposure to UV radiation by using sunscreen creams, wearing protective clothing, and self-monitoring the skin. Before irradiation treatment is started, patients should undergo a detailed derma- pacjentów wykazała, że zwiększone ryzyko występuje po 15 latach od pierwszego zastosowania naświetlań PUVA, zwłaszcza u pacjentów, którzy przeszli $\geq 250$ zabiegów [42]. Jednak europejskie prace do tej pory nie potwierdziły tej zależności. W badaniu szwedzkim z udziałem 4799 pacjentów obserwowanych przez średnio 15,9 roku nie stwierdzono wzrostu zapadalności na czerniaka, co może wynikać z innego schematu terapeutycznego w USA i Europie oraz różnych kryteriów doboru chorych do badania [39].

Przeciwwskazania do fototerapii zostały przedstawione $\mathrm{w}$ tabeli 1.

W celu zapobiegania działaniom niepożądanym fototerapii w trakcie zabiegów należy stosować gogle ochronne oraz zasłonić okolice o zwiększonej ekspozycji na słońce: twarz, szyję, barki, ręce, jeśli nie są one zajęte przez zmiany skórne. Bardzo ważne jest osłanianie okolic genitalnych podczas naświetlań, ponieważ wykazano, że niestosowanie okrycia powoduje wzrost ryzyka wystąpienia nowotworów w tych miejscach [43]. Pacjentów należy edukować, by chronili się przed dodatkową nadmierną ekspozycją na promieniowanie UV poprzez stosowanie kremów

Table I. Contraindications to the use of phototherapy $[1,6,8]$

\begin{tabular}{ll}
\multicolumn{1}{c}{ Absolute } & Relative \\
- Malignant skin cancers & - Epilepsy \\
- Lupus erythematosus & - Photosensitizing drugs \\
- Genophotodermatoses, genodermatoses, including: & - Dysplastic nevus syndrome \\
- xeroderma pigmentosum & - History of malignant melanoma/several NMSC \\
- Cockayne syndrome & - Skin phototype I (II in people with a tendency to sunburn) \\
- Bloom syndrome & - Lack of patient compliance \\
& - Physical or mental impairment (NYHA III-IV, claustrophobia, \\
& conditions preventing prolonged standing/body heating) \\
\hline Additionally applicable to PUVA: & - Prior treatment with arsenic agents/ionizing radiation therapy \\
- treatment with cyclosporin A & Additionally applicable to PUVA: \\
- pregnancy and breast-feeding & - high cumulative dose (> I 50-200 irradiation treatments) \\
- porphyria & - caution $<$ I 8 years of age \\
& - severe liver diseases (oral PUVA) \\
\hline
\end{tabular}

Tabela I. Przeciwwskazania do stosowania fototerapii $[1,6,8]$

\begin{tabular}{ll}
\multicolumn{1}{c}{ Bezwzględne } & Względne \\
- Złośliwe nowotwory skóry & - Padaczka \\
- Toczeń rumieniowaty & - Leki fotouczulające \\
- Genofotodermatozy, genodermatozy, m.in.: & - Zespół znamion atypowych \\
- xeroderma pigmentosum & - Czerniak w wywiadzie lub kilka NMSC \\
- zespół Cockayne'a & - Fototyp skóry I (II u osób z tendencją do oparzeń słonecznych) \\
- zespół Blooma & - Brak współpracy \\
& - Niesprawność fizyczna lub psychiczna (NYHA III-IV, \\
& klaustrofobia, stan uniemożliwiający długie stanie lub \\
& nagrzewanie ciała) \\
\hline Dodatkowo dla PUVA: & - Stosowanie preparatów z arszenikiem lub terapii \\
- leczenie cyklosporyną A & promieniowaniem jonizującym w wywiadzie \\
- ciąża i karmienie piersią & Dodatkowo dla PUVA: \\
- porfiria & - duża dawka kumulacyjna (> I 50-200 naświetlań) \\
\hline
\end{tabular}


tological assessment. In addition, they require regular monitoring of skin condition $[1,9]$.

According to existing recommendations patients undergoing > 150-200 PUVA sessions should receive special long-term dermatological care. Skin examination in these patients should be carried out once a year, even for the entire lifetime, as a precaution to prevent the development of skin cancer $[1,8,9]$. As the risk of cancer occurrence rises along with increasing cumulative dose, it should be closely monitored in each patient. According to the European guidelines the cumulative lifetime UVA dose should be limited to $1000 \mathrm{~J} / \mathrm{cm}^{2}$ [1].

During PUVA therapy it is necessary to wear protective goggles with UVA filter from the time of taking oral psoralens for the next 8 hours. Some sources recommend wearing glasses for 12 hours following irradiation $[1,9]$.

During the assessment of patient eligibility for phototherapy, a detailed history of drugs taken by the patient should be collected, focusing on phototoxic and photosensitizing agents.

\section{CONCLUSIONS}

Despite advances in the understanding of the pathogenesis of psoriasis, and the development of multiple new drugs with various new mechanisms contributing to improved disease control, the importance of phototherapy as an effective form of psoriasis treatment should not be underestimated. The efficacy of the method is often equivalent to that of systemic therapies. In addition, phototherapy has a very high safety profile with a low rate of adverse effects. During the assessment of patient eligibility for irradiation treatment it needs to be ensured that there are no contraindications to using this therapeutic option. In addition, patients must be regularly followed-up throughout the treatment and informed about methods aimed at preventing adverse effects. Also, detailed records must be kept to ensure that the maximum cumulative radiation dose is not exceeded.

\section{ACKNOWLEDGMENTS}

The study has been financed from the statutory funds of the Medical University of Lodz (503/5-06401/503-01) and from the grant no. UMO -2013/11/ B/NZ5/00037.

\section{CONFLICT OF INTEREST}

The authors declare no conflict of interest. z filtrem UV, odzieży ochronnej oraz by samodzielnie obserwowali skórę. Przed rozpoczęciem naświetlań pacjenci powinni zostać szczegółowo zbadani przez dermatologa, a monitorowanie stanu skóry należy wykonywać systematycznie [1,9].

Istnieją zalecenia, aby pacjentów poddanych > 150-200 sesjom naświetlań PUVA objąć szczególną długoterminową opieką dermatologiczną. Badanie skóry u tych osób powinno się przeprowadzać raz w roku nawet do końca życia, by wykluczyć rozwój nowotworu skóry [1,8,9]. Ryzyko jego wystąpienia zwiększa się wraz ze wzrostem dawki kumulacyjnej, dlatego należy ją ściśle monitorować u każdego pacjenta. Zgodnie z rekomendacjami europejskimi nie należy przekraczać skumulowanej dawki UVA $1000 \mathrm{~J} / \mathrm{cm}^{2}$ w czasie całego życia [1].

W trakcie PUVA-terapii konieczne jest używanie okularów ochronnych z filtrem UVA od momentu przyjęcia doustnych psoralenów i przez kolejne 8 godzin, a niektóre źródła zalecają noszenie okularów przez 12 godzin po naświetlaniu $[1,9]$.

W trakcie kwalifikacji pacjenta do fototerapii należy zebrać dokładny wywiad dotyczący przyjmowanych leków, zwracając uwagę na leki fototoksyczne i fotouczulające.

\section{WNIOSKI}

Mimo coraz lepszego poznania patogenezy łuszczycy i powstawania wielu nowych leków, które w różnorodnych nowych mechanizmach wpływają na poprawę kontroli choroby, nie należy zapominać o skutecznej formie leczenia, jaką jest fototerapia. Metoda ta niejednokrotnie nie odbiega skutecznością od leczenia ogólnego, charakteryzuje się przy tym bardzo wysokim profilem bezpieczeństwa i niskim odsetkiem działań niepożądanych. Ważne jest, by podczas kwalifikacji do naświetlań upewnić się, że nie ma przeciwwskazań do ich stosowania. Należy też pamiętać, by systematycznie monitorować pacjenta, poinformować go o metodach zapobiegania wystąpieniu działań niepożądanych, jak również prowadzić szczegółową dokumentację, by nie przekroczyć maksymalnej skumulowanej dawki promieniowania.

\section{PODZIĘKOWANIA}

Praca finansowana $\mathrm{z}$ funduszu pracy statutowej Uniwersytetu Medycznego w Łodzi 503/5-064-01/50301, a także z grantu UMO -2013/11/B/NZ5/00037.

\section{KONFLIKT INTERESÓW}

Autorzy nie zgłaszają konfliktu interesów. 


\section{References}

\section{Piśmiennictwo}

1. Pathirana D., Ormerod A.D., Saiag P., Smith C., Spuls P.I., Nast A., et al.: European S3-guidelines on the systemic treatment of psoriasis vulgaris. J Eur Acad Dermatol Venereol 2009, 23 (Suppl 2), 1-70.

2. Matos T.R., Sheth V.: The symbiosis of phototherapy and photoimmunology. Clin Dermatol 2016, 34, 538-547.

3. Krutmann J., Morita A.: Mechanisms of ultraviolet (UV) B and UVA phototherapy. J Investig Dermatol Symp Proc 1999, 4, 70-72.

4. Ibbotson S.H., Bilsland D., Cox N.H., Dawe R.S., Diffey B., Edwards C., et al.: An update and guidance on narrowband ultraviolet B phototherapy: a British Photodermatology Group Workshop Report. Br J Dermatol 2004, 151, $283-297$.

5. Zanolli M.: Phototherapy treatment of psoriasis today. J Am Acad Dermatol 2003, 49 (2 Suppl), 78-86.

6. Menter A., Korman N.J., Elmets C.A., Feldman S.R., Gelfand J.M., Gordon K.B., et al.: Guidelines of care for the management of psoriasis and psoriatic arthritis: section 5. Guidelines of care for the treatment of psoriasis with phototherapy and photochemotherapy. J Am Acad Dermatol 2010, 62, 114-135.

7. Mrowietz U., Kragballe K., Reich K., Spuls P., Griffiths C.E., Nast A., et al.: Definition of treatment goals for moderate to severe psoriasis: a European consensus. Arch Dermatol Res 2011, 303, 1-10.

8. Samarasekera E., Sawyer L., Parnham J., Smith C.H.: Guideline Development Group. Assessment and management of psoriasis: summary of NICE guidance. BMJ 2012, 345: e6712.

9. Ling T.C., Clayton T.H., Crawley J., Exton L.S., Goulden V., Ibbotson S., et al.: British Association of Dermatologists and British Photodermatology Group guidelines for the safe and effective use of psoralen-ultraviolet A therapy 2015. Br J Dermatol 2016, 174, 24-55.

10. Matos T.R., Ling T.C., Sheth V.: Ultraviolet B radiation therapy for psoriasis: pursuing the optimal regime. Clin Dermatol 2016, 34, 587-593.

11. Almutawa F., Alnomair N., Wang Y., Hamzavi I., Lim H.W.: Systematic review of UV-based therapy for psoriasis. Am J Clin Dermatol 2013, 14, 87-109.

12. Lowe N.J., Prystowsky J.H., Bourget T., Edelstein J., Nychay S., Armstrong R.: Acitretin plus UVB therapy for psoriasis. Comparisons with placebo plus UVB and acitretin alone. J Am Acad Dermatol 1991, 24, 591-594.

13. Koo J.Y., Lowe N.J., Lew-Kaya D.A., Vasilopoulos A.I., Lue J.C., Sefton J., et al.: Tazarotene plus UVB phototherapy in the treatment of psoriasis. J Am Acad Dermatol 2000, 43, 821-828.

14. Woo W.K., McKenna K.E.: Combination TL01 ultraviolet B phototherapy and topical calcipotriol for psoriasis: a prospective randomized placebo-controlled clinical trial. Br J Dermatol 2003, 149, 146-150.

15. Berneburg M., Herzinger T., Rampf J., Hoetzenecker W., Guenova E., Meisner C., et al.: Efficacy of bath psoralen plus ultraviolet A (PUVA) vs. system PUVA in psoriasis: a prospective, open, randomized, multicentre study. Br J Dermatol 2013, 169, 704-708.

16. Berg M., Ros A.M.: Treatment of psoriasis with psoralens and ultrafiolet A. A double-blind comparison of 8-methoxypsoralen and 5-methoxypsoralen. Photodermatol Photoimmunol Photomed 1994, 10, 217-220.

17. Nijsten T.E., Stern R.S.: Oral retinoid use reduces cutaneous squamous cell carcinoma risk in patients with psoriasis treated with psoralen-UVA: a nested cohort study. J Am Acad Dermatol 2003, 49, 644-650.

18. Torras H., Aliaga A., López-Estebaranz J.L., Hernández I., Gardeazabal J., Quintanilla E., et al.: A combination therapy of calcipotriol cream and PUVA reduces the UVA dose and improves the response of psoriasis vulgaris. J Dermatolog Treat 2004, 15, 98-103.

19. Marcil I., Stern R.S.: Squamous-cell cancer of the skin in patients given PUVA and ciclosporin: nested cohort-crossover study. Lancet 2001, 358, 1042-1045.

20. Shehzad T., Dar N.R., Zakria M.: Efficacy of concomitant use of PUVA and methotrexate in disease clearance time in plaque type psoriasis. J Pak Med Assoc 2004, 54, 453-455.

21. MacKie R.M., Fitzsimons C.P.: Risk of carcinogenicity in patients with psoriasis treated with methotrexate or PUVA singly or in combination. J Am Acad Dermatol 1983, 9, 467-469.

22. Weinstabl A., Hoff-Lesch S., Merk H.F., von Felbert V.: Prospective randomized study on the efficacy of blue light in the treatment of psoriasis vulgaris. Dermatology 2011, 223, 251-259.

23. Pfaff S., Liebmann J., Born M., Merk H.F., von Felbert V.: Prospective randomized long-term study on the efficacy and safety of UV-free blue light for treating mild psoriasis vulgaris. Dermatology 2015, 231, 24-34.

24. Crall C.S., Rork J.F., Delano S., Huang J.T.: Phototherapy in children: considerations and indications. Clin Dermatol 2016, 34, 633-639.

25. Napolitano M., Megna M., Balato A., Ayala F., Lembo S., Villani A., et al.: Systemic treatment of pediatric psoriasis: a review. Dermatol Ther (Heidelb) 2016, 6, 125-142.

26. Ersoy-Evans S., Altaykan A., Sahin S., Kölemen F.: Phototherapy in childhod. Pediatr Dermatol 2008, 25, 599-605.

27. Holme S.A., Anstey A.V.: Phototherapy and PUVA photochemotherapy in children. Photodermatol Photoimmunol Photomed 2004, 20, 69-75.

28. Zamberk P., Velázquez D., Campos M., Hernanz J.M., Lázaro P.: Paediatric psoriasis - narrowband UVB treatment. J Eur Acad Dermatol Venereol 2010, 24, 415-419.

29. Hoffman M.B., Farhangian M., Feldman S.R.: Psoriasis during pregnancy: characteristics and important management recommendations. Expert Rev Clin Immunol 2015, 11, 709-720.

30. Bangsgaard N., Rørbye C., Skov L.: Treating psoriasis during pregnancy: safety and efficacy of treatments. Am J Clin Dermatol 2015, 16, 389-398.

31. Bae Y.S., Van Voorhees A.S., Hsu S., Korman N.J., Lebwohl M.G., Young M., et al.: Review of treatment options for psoriasis in pregnant or lactating women: from the Medical Board of the National Psoriasis Foundation. J Am Acad Dermatol 2012, 67, 459-477. 
32. Laube S., George S.A.: Adverse effects with PUVA and UVB phototherapy. J Dermatolog Treat 2001, 12, 101-105.

33. Monteiro A.F., Rato M., Martins C.: Drug-induced photosensitivity: photoallergic and phototoxic reactions. Clin Dermatol 2016, 34, 571-581.

34. Valejo Coelho M.M., Matos T.R., Apetato M.: The dark side of the light: mechanisms of photocarcinogenesis. Clin Dermatol 2016, 34, 563-570

35. Hearn R.M., Kerr A.C., Rahim K.F., Ferguson J., Dawe R.S.: Incidence of skin cancers in 3867 patients treated with narrowband ultraviolet B phototherapy. Br J Dermatol 2008, 159, 931-935.

36. Archier E., Devaux S., Castela E., Gallini A., Aubin F., Le Maître M., et al.: Carcinogenic risks of psoralen UV-A therapy and narrowband UV-B therapy in chronic plaque psoriasis: a systematic literature review. J Eur Acad Dermatol Venereol 2012 , 26 (Suppl 3), 22-31.

37. Valejo Coelho M.M., Apetato M.: The dark side of the light: phototherapy adverse effects. Clin Dermatol 2016, $34,556-562$.

38. Malanos D., Stern R.S.: Psoralen plus ultraviolet A does not increase the risk of cataracts: a 25-year prospective study. J Am Acad Dermatol 2007, 57, 231-237.

39. Lindelöf B., Sigurgeirsson B., Tegner E., Larkö O., Johannesson A., Berne B., et al.: PUVA and cancer risk: the Swedish follow-up study. Br J Dermatol 1999, 141, 108-112.

40. Stern R.S.; PUVA Follow-Up Study.: The risk of squamous cell and basal cell cancer associated with psoralen and ultraviolet A therapy: a 30-year prospective study. J Am Acad Dermatol 2012, 66, 553-562.

41. Nijsten T.E., Stern R.S.: The increased risk of skin cancer is persistent after discontinuation of psoralen + ultraviolet A: a cohort study. J Invest Dermatol 2003, 121, 252-258.

42. Stern R.S., Nichols K.T., Väkevä L.H.: Malignant melanoma in patients treated for psoriasis with methoxsalen (psoralen) and ultraviolet A radiation (PUVA). The PUVA Follow-Up Study. N Engl J Med 1997, 336, 1041-1045.

43. Stern R.S.: Genital tumors among men with psoriasis exposed to psoralens and ultraviolet A radiation (PUVA) and ultraviolet B radiation. The photochemotherapy follow-up study. N Engl J Med 1990, 322, 1093-1097.

Received: 29.01.2019

Accepted: 24.04 .2019

Otrzymano: 29.01.2019 r.

Zaakceptowano: 24.04 .2019 r.

How to cite this article

Sadowska M., Lesiak A., Narbutt J.: Application of phototherapy in the treatment of psoriasis vulgaris. Dermatol Rev/Przegl Dermatol 2019, 106, 198-209. DOI: https://doi.org/10.5114/dr.2019.85577. 